\title{
Clinical, HLA, and roentgenological follow up study of patients with juvenile arthritis: comparison between the long term outcome of transient and persistent arthritis in children
}

\author{
HÅKAN STRÖM, ${ }^{15}$ NILS LINDVALL, ${ }^{2}$ BO HELLSTRÖM, ${ }^{3 *}$ \\ AND LILI ROSENTHAL
}

From the ${ }^{1}$ Department of Internal Medicine, Division of Rheumatology, Danderyd Hospital; the Departmentsō of ${ }^{2}$ Radiology, ${ }^{3}$ Pediatrics, and ${ }^{4}$ Rheumatology, Karolinska Hospital; and the ${ }^{5}$ Department of Clinical $\dot{5}_{\infty}$ Immunology, Huddinge Hospital, Karolinska Institute, Stockholm, Sweden

SUMMARY Fifty two patients with juvenile chronic arthritis (JCA) and 22 patients with arthritis? of short duration (transient arthritis, TA) were studied in a follow up investigation. Nineteen$(37 \%)$ of the patients with JCA had peripheral arthritis or sequelae in the form of contractures ato follow up, and in addition one patient was treated with corticosteroids. In contrast, only oneo $(5 \%)$ of the 22 patients with TA had peripheral arthritis at follow up. Back pain or limitation, or both, was registered in many of the men. Sacroiliitis, verified by $x$ ray, was often found both in? JCA $(39 / 46,85 \%)$ and in TA $(16 / 21,76 \%)$. For JCA an association was confirmed with HLA- 220 and HLA-DRw8 and a negative association with HLA-DR4, and in pauciarticular JCA, inc addition, a decrease of DR7. A new finding was a low prevalence of HLA-B27 in women whith JCA and grade 3 or 4 sacroiliitis $(2 / 14,14 \%)$.

Juvenile chronic arthritis (JCA) is a heterogeneous group of disorders, ${ }^{12}$ subclassified depending on the mode of onset into pauciarticular, polyarticular, and systemic forms.

Earlier studies on JCA showed multiple associations with HLA antigens: increased prevalence of A2, Dw5, DR5, Dw8, DRw8 and decreased prevalence of DR4 ${ }^{3}, \mathrm{Dw} 2$, and Dw $7^{4}$ in JCA. Even in pauciarticular JCA increased prevalence of $A 2$, DR5, and DRw8 and decreased prevalence of DR4 and DR7 have been found. ${ }^{5}$ An increased prevalence of HLA-B27 has been found in men but not women with pauciarticular disease, and is not found in patients with polyarticular disease. ${ }^{6}$

To fulfil the EULAR criteria ${ }^{7}$ patients with JCA must have had arthritis lasting for at least three months. According to the American criteria for juvenile rheumatoid arthritis, ${ }^{8}$ six weeks is the minimum duration. To our knowledge no study has

Accepted for publication 28 February 1989.

Correspondence to Dr Håkan Ström, Department of Clinical Immunology, F79, Huddinge Hospital, S-141 86 Huddinge, Sweden.

${ }^{*}$ Deceased. so far analysed possible HLA associations in a group $\stackrel{\varnothing}{\varnothing}$ of patients with arthritis of shorter duration than $\overrightarrow{\overrightarrow{0}}$ three months (designated transient arthritis (TA) in 3 this study). The purpose of this study was to establish the outcome of inpatients with an initial? presentation of arthritis and to find out whether the HLA antigens, with known associations to JCA, would differ between patients with peripheral 3 arthritis at follow up and those without, and also to analyse the prevalence of sacroiliitis and spondylitis, especially in relation to HLA-B27.

\section{Patients and methods}

\section{PATIENTS}

The medical records of children treated for arthritis as inpatients at the Karolinska Hospital and the $\mathrm{St}$. Göran Hospital in Stockholm during 1950-1970 were examined. One hundred and twenty cases of aseptic arthritis were found and these individualso were contacted by letter or telephone. Eighty oneळ patients were willing to participate in the follow up? study. The EULAR criteria for juvenile chronic arthritis (JCA) were applied. ${ }^{7}$ Three patients who $\frac{\text { ? }}{8}$ 
had arthralgia but no objective arthritis were excluded, and, additionally, four patients were excluded because of lack of adequate information in the medical records. Fifty two patients fulfilled the criteria for JCA. Of these, four patients had systemic onset with persistent intermittent fever and three of them also had rash, lymphadenopathy, or splenomegaly. Twenty two patients had had arthritis lasting less than three months and were classified as having had transient arthritis (TA). All were unrelated white Caucasians.

For the JCA group the mean age at follow up was 25 years (range 13-41) and for the TA group 26 years (range 13-41), and the mean observation time was 18 years for both JCA (range 5-35) and TA (range 5-32). Table 1 shows the mean age at onset for the different forms of JCA. For women with pauciarticular onset the debut age was $<9$ years in 23 cases and $\geqslant 9$ years in eight cases, while for the men with pauciarticular onset the corresponding ages were 5 and 7 respectively.

Mean age at onset for the children with TA was 8 years for both male and female patients.

The patients were interviewed and the joints and the mobility of the back of each patient was investigated clinically.

\section{LABORATORY TESTS AND HLA TYPING}

Laboratory tests included a complete blood count, erythrocyte sedimentation rate Westergren, urine analysis, rheumatoid factor according to the Svartz technique, ${ }^{9}$ and antinuclear antibodies. The antinuclear antibodies were determined by indirect immunofluorescence using cryostat sections of rat kidneys; a titre of $\geqslant 1 / 25$ was considered positive. Typing for HLA A, B, C, and DR was performed. ${ }^{10} 11$ The notation $x$ was used for an unknown antigen. As an example, DR1, $x$ denotes an individual who has the antigen DR1 and an unknown antigen or, alternatively, is homozygous for DR1. Seventy eight ethnically matched, normal individuals (laboratory staff) served as controls for the HLA analysis.

Table 1 Mean onset age in years, juvenile chronic arthritis (JCA)

\begin{tabular}{lccll}
\hline & \multirow{2}{*}{$\begin{array}{c}M / F \\
(N o)\end{array}$} & \multicolumn{3}{l}{ Onset age (years) } \\
\cline { 3 - 5 } & & Men & Women & Total \\
\hline Pauciarticular & $12 / 31$ & 8 & 6 & 6 \\
Polyarticular & $1 / 4$ & 13 & 5 & 6 \\
Systemic & $3 / 1$ & 6 & 5 & 6 \\
All JCA & & 8 & 6 & 6 \\
\hline
\end{tabular}

Table 2 Classification of $x$ ray abnormalities in the sacroiliac joints*

\begin{tabular}{|c|c|}
\hline Grade & Abnormality \\
\hline 0 & Normal joints \\
\hline 1 & Suspicious changes without specific abnormality \\
\hline 2 & Edges not distinct \\
\hline & $\begin{array}{l}\text { Minimal sclerosis and minimal erosions } \\
\text { Some narrowing of the joint space }\end{array}$ \\
\hline 3 & Definite sclerosis \\
\hline & Shaggy joint surfaces and erosive changes \\
\hline 4 & $\begin{array}{l}\text { Complete fusion or ankylosis with or without } \\
\text { remaining sclerosis }\end{array}$ \\
\hline
\end{tabular}

${ }^{*}$ According to a modification of the New York criteria. ${ }^{12}$

ROENTGENOLOGICAL EXAMINATION

With the patients' consent and permission from the ethical committee, radiological examinations of lower thoracic and lumbar spine were performed. The sacroiliac joints were $x$ rayed using two projections: one from the anteroposterior view of the pelvis with the subject supine, the $x$ ray tube angled 25 degrees caudocephalad, and one with the patient in the prone position without angulation of the tube. Both projections included both sacroiliac joints. As controls we used a series of consecutive $x$ ray investigations of the back of patients in hospital, whose working capacity was being investigated or who were inpatients for rehabilitation purpose: 93 men aged 20-63 and 128 women aged 26-65; most being between 45 and 55 years of age. Some of them had backache due to spondyloarthrosis. We were not able to exclude previously undiagnosed clinical sacroiliitis. The changes in the sacroiliac joints were classified according to a modified version of the New York criteria $^{12}$ (Table 2). The radiographs were evaluated on two different occasions by the same radiologist (NL); on the second assessment the radiologist had no knowledge of the findings of the first evaluation. Grades $\geqslant 2$ were scored as signs of sacroiliitis. The sacroiliac joints on either side were graded separately. In a few cases where the gradings

Table 3 Patients with back pain or limitation, or both

\begin{tabular}{llllll}
\hline & \multicolumn{1}{l}{$J A^{*}$} & & \multicolumn{2}{l}{$T A^{*}$} \\
\cline { 2 - 3 } \cline { 5 - 6 } & $\begin{array}{l}\text { Men } \\
(n=16)\end{array}$ & $\begin{array}{l}\text { Women } \\
(n=36)\end{array}$ & & $\begin{array}{l}\text { Men } \\
(n=11)\end{array}$ & $\begin{array}{l}\text { Women } \\
(n=11)\end{array}$ \\
\hline Back pain & 5 & 0 & 2 & 0 \\
Limitation & 5 & 6 & & 1 & 4 \\
Limitation and back pain & 0 & 2 & & 1 & 1 \\
No evaluation & 1 & 4 & 1 & 1 \\
\hline
\end{tabular}

*JCA= juvenile chronic arthritis; $\mathrm{TA}=$ transient arthritis. 
for the right and left joint differed the highest grade was scored. A complete $x$ ray examination of the hips was performed in three individuals. Clinical, laboratory, and radiographic examinations were all performed separately without knowledge of the results of the other investigations or of HLA determination.

\section{STATISTICAL METHODS}

Statistical analysis was performed by Fisher's exact test. In cases where no a priori hypothesis had been formulated the $p$ values were corrected $\left(p_{c}\right)$ by multiplying them by the number of tests made and, secondly, Fisher's two sided test was used. The following comparisons performed in this investigation were subject to an a priori hypothesis based on results published earlier ${ }^{3-5}$ : increased prevalence of A2, DR5, DRw8, low prevalence of DR4 and DR7. In these instances a one sided Fisher's test was used.

\section{Results}

CLINICAL MANIFESTATIONS AT FOLLOW UP Arthritis

Nineteen patients $(37 \%)$ in the JCA group (seven men, 12 women) had signs of arthritis or sequelae in the form of contractures at the clinical follow up examination. Of these, two men and seven women (one with bilateral prosthesis) had clinical signs of hip joint involvement. In addition, one man with systemic onset JCA was receiving treatment with corticosteroids. One man in the TA group had moderate restriction of abduction in the right hip, but the remaining patients were free of arthritis at follow up.

\section{Back pain or limitation, or both}

Table 3 gives details of patients with back pain or limitation, or both.

\section{Eye manifestations}

Thirteen $(25 \%)$ (seven men, six women) patients in

Table 4 Functional class according to Steinbrocker ${ }^{13}$

\begin{tabular}{llllll}
\hline $\begin{array}{l}\text { Functional } \\
\text { class }\end{array}$ & \multicolumn{2}{l}{$\mathrm{JA}^{*}(n=52)$} & $\begin{array}{l}T A^{*} \\
(n=22)\end{array}$ & $\begin{array}{l}\text { Total } \\
(n=74)\end{array}$ \\
\cline { 2 - 4 } & $\begin{array}{l}\text { Pauci } \\
(n=43)\end{array}$ & $\begin{array}{l}\text { Poly } \\
(n=5)\end{array}$ & $\begin{array}{l}\text { Systemic } \\
(n=4)\end{array}$ & & \\
\hline I & 26 & 1 & 3 & 17 & 47 \\
II & 14 & 1 & 0 & 4 & 19 \\
III & 0 & 3 & 1 & 0 & 4 \\
IV & 2 & 0 & 0 & $1 \dagger$ & 3 \\
ND* & 1 & 0 & 0 & 0 & 1
\end{tabular}

${ }^{*} \mathrm{JCA}=$ juvenile chronic arthritis; $\mathrm{TA}=$ transient arthritis; $\mathrm{ND}=$ not done.

$\nmid$ Neurological disease.
Table $5 x$ Ray abnormalities of the sacroiliac joints in JCA* and TA*

\begin{tabular}{|c|c|c|c|c|c|c|c|}
\hline \multirow{2}{*}{$\begin{array}{l}x \text { Ray } \\
\text { changes }\end{array}$} & \multicolumn{2}{|c|}{$J C A \quad(n=52)$} & \multicolumn{2}{|c|}{$T A(n=22)$} & \multicolumn{3}{|c|}{ Controls $(n=221)$ 离 } \\
\hline & $\begin{array}{l}\text { Men } \\
(n=16)\end{array}$ & $\begin{array}{l}\text { Women } \\
(n=36)\end{array}$ & $\begin{array}{l}\text { Men } \\
(n=11)\end{array}$ & $\begin{array}{l}\text { Women } \\
(n=11)\end{array}$ & $\begin{array}{l}\text { Men } \\
(n=93)\end{array}$ & $\begin{array}{l}\text { Women } \\
(n=128)\end{array}$ & 음 \\
\hline 0 & 1 & 4 & 1 & 2 & 70 & 76 & (D) \\
\hline 1 & 2 & 0 & 1 & 1 & 8 & 23 & \\
\hline 2 & 5 & 12 & 6 & 4 & & & ע \\
\hline 3 & 6 & 12 & 3 & 3 & 15 & 29 & \\
\hline 4 & 2 & 2 & 0 & 0 & & & \\
\hline $\mathrm{ND}^{*}$ & 0 & 6 & 0 & 1 & 0 & 0 & \\
\hline
\end{tabular}

*JCA = juvenile chronic arthritis; $\mathrm{TA}=$ transient arthritis; $\mathrm{ND}=$ not done.

the JCA group, but none in the TA group, had a $\overrightarrow{\vec{t}}$ history of acute or chronic uveitis.

\section{Psoriasis}

Three cases of psoriasis were found in the JCA group and one in the TA group.

\section{Laboratory data}

At the follow up examination the erythrocyte $\stackrel{\mathbb{D}}{-}$ sedimentation rate was $>20 \mathrm{~mm} / \mathrm{h}$ in four women $\overrightarrow{0}$ and $>15 \mathrm{~mm} / \mathrm{h}$ in two men with JCA, but it ws normal in all patients with TA. Seven of the womed. in the JCA group had positive antinuclear ant bodies of low titre. None of the men in the JCA group and none in the TA group, however, were positive for antinuclear antibodies. Only two women with positive antinuclear antibodies had arthritis or $\mathbb{Q}$ signs of arthritis at follow up. A positive rheumatoid $\overrightarrow{\vec{O}}$ factor test was recorded in one case (a 33 year old $\exists$ woman with TA) at follow up.

\section{Functional class}

Table 4 shows the functional class ${ }^{13}$ at the time of the follow up of the patients with JCA and TA.

RA D I OG RA P H I C F IN D IN GS
Table 5 presents the results of $x$ ray investigations of the sacroiliac joints. The prevalence of sacroiliitis in음 JCA was $85 \%(39 / 46)$, in TA $76 \%(16 / 21)$, and in controls $20 \%(44 / 221)$. Five men and 15 women were $<20$ years of age at follow up. Of these, threen men and seven women had grade 1 or 2 sacroiliitis. In these 10 patients the evaluation of the radio- 0 graphs was difficult as during growth the radiographicw outline of the cortical margins of the joints is normally ill defined. ${ }^{14}$

Twenty two of 46 patients with JCA $(48 \%)$ and $6 / 21(29 \%)$ of patients with TA had sacroiliitis grade? $\geqslant 3$. Three of the seven $(43 \%)$ men with JCA and arthritis at follow up had sacroiliitis grade $\geqslant 3$, 요 
whereas of the nine men who had no arthritis at follow up, five $(56 \%)$ had sacroiliitis grade $\geqslant 3$. For girls with JCA the corresponding figures were $5 / 11$ (45\%) and $9 / 19(47 \%)$ respectively. Of the 10 men with JCA and back pain or stiffness, or both, seven had sacroiliitis grade $\geqslant 3$; of the eight women with JCA and back pain or stiffness, or both, two had sacroiliitis grade $\geqslant 3$ (two were not $x$ rayed). In three patients, who had bilateral sacroiliitis grade 3 , spondylitis was found.

\section{RESULT OF THE TISSUE TYPING}

Tables 6,7 , and 8 present the results of HLA-A, B, $C$, and DR antigen determinations for all patients with JCA, for pauciarticular JCA, and for TA.

There was no deviation for HLA-B27 in patients with peripheral arthritis at follow up. Seven of the 10 men with JCA who had back pain or limitation, or both, at follow up were B27 positive, while all the eight women were B27 negative.

In patients with sacroiliitis $7 / 13$ men and $5 / 26$ women were HLA-B27 positive. When only grade 3 or 4 sacroiliitis was considered we found that only $2 / 14$ women $(14 \%)$ were HLA-B27 positive, whereas this antigen was found in $6 / 8$ men (75\%) (Fisher's two sided test, $\mathrm{p}<0.01) ; \mathrm{p}_{\mathrm{c}}$ values were not significant.

The cases with spondylitis included two HLA-B27 negative women and one HLA-B27 positive man. None of them had psoriasis, colitis, or Crohn's disease.

Of women in the JCA group with pauciarticular

Table 6 Prevalence (\%) of selected $H L A-A, B, C$, and $D R$ antigens in patients with juvenile chronic arthritis compared with controls

\begin{tabular}{lllll}
\hline$H L A$ & Patients & & & $\begin{array}{l}\text { Controls } \\
(n=78)\end{array}$ \\
\cline { 2 - 5 } & $\begin{array}{l}\text { Men } \\
(n=16)\end{array}$ & $\begin{array}{c}\text { Women } \\
(n=36)\end{array}$ & $\begin{array}{l}\text { All } \\
(n=52)\end{array}$ & \\
\hline A2 & 75 & $75^{*}$ & $75^{*}$ & 54 \\
A28 & 6 & 6 & $6 \dagger$ & 21 \\
B12 & 6 & 14 & $12 \dagger$ & 29 \\
B27 & $44+\dagger$ & 14 & $23 \dagger$ & 10 \\
Cw2 & $25 \dagger$ & 8 & 13 & 6 \\
DR1 & 19 & 14 & 15 & 10 \\
DR2 & $0+\dagger$ & $14 \dagger$ & $10+\dagger$ & 33 \\
DR3 & 25 & 31 & 31 & 19 \\
DR4 & $13^{*}$ & $11^{* *}$ & $12^{* * *}$ & 37 \\
DR5 & 13 & 11 & 12 & 10 \\
DRw6 & 0 & 6 & 4 & 10 \\
DR7 & 13 & $3+\dagger \dagger$ & $6+\dagger \dagger$ & 28 \\
DRw8 & $31^{*}$ & $47^{* * *}$ & $40^{* * *}$ & 9 \\
\hline
\end{tabular}

${ }^{*} \mathrm{p}<0.05 ;{ }^{* *} \mathrm{p}<0.01 ;{ }^{* * *} \mathrm{p}<0.001$; all Fisher's one sided test. $+p<0.05 ;++p<0.01 ;++\dagger p<0.001$; all Fisher's two sided test.
Table 7 Prevalence (\%) of selected $H L A-A, B, C$, and $D R$ antigens in patients with juvenile chronic arthritis of pauciarticular onset compared with controls

\begin{tabular}{lllll}
\hline HLA & Patients & & & $\begin{array}{l}\text { Controls } \\
(n=78)\end{array}$ \\
\cline { 2 - 4 } & $\begin{array}{l}\text { Men } \\
(n=12)\end{array}$ & $\begin{array}{l}\text { Women } \\
(n=31)\end{array}$ & $\begin{array}{l}\text { All } \\
(n=43)\end{array}$ & \\
\hline A2 & 75 & $81^{* *}$ & $79^{* *}$ & 54 \\
A3 & 17 & $13 \dagger$ & $14 \dagger \dagger$ & 38 \\
B27 & 33 & 10 & 16 & 10 \\
Cw1 & 0 & 0 & $0 \dagger$ & 12 \\
DR1 & 8 & 16 & 14 & 10 \\
DR2 & $0 \dagger$ & 16 & $12 \dagger \dagger$ & 33 \\
DR3 & $42 \dagger$ & 26 & 30 & 19 \\
DR4 & $8^{*}$ & $10^{* *}$ & $9^{* * *}$ & 37 \\
DR5 & 8 & 13 & 12 & 10 \\
DRw6 & 0 & 7 & 5 & 10 \\
DR7 & 8 & $3^{* *}$ & $5^{* *}$ & 28 \\
DRw8 & $42^{* *}$ & $45^{* * *}$ & $44^{* * *}$ & 9 \\
\hline
\end{tabular}

${ }^{*} \mathrm{p}<0.05 ;{ }^{* *} \mathrm{p}<0.01 ;{ }^{* * *} \mathrm{p}<0.001$; all Fisher's one sided test. $+\mathrm{p}<0.05 ; \dagger+\mathrm{p}<0.01$; both Fisher's two sided test.

onset and arthritis or sequelae of arthritis at follow up, only $1 / 8(13 \%)$ had HLA-DRw8 compared with $13 / 23(57 \%)$ with pauciarticular onset who were free of arthritis and sequelae of arthritis at follow up; the uncorrected $p$ value was significant (Fisher's two sided test, $\mathrm{p}<0 \cdot 05$ ), but not the corrected $\mathrm{p}$ value. Of the eight women with pauciarticular onset and arthritis or sequelae at follow up, four had polyarticular disease at the time of the follow up examination and the HLA-DR phenotypes of these patients were: $1, \mathbf{x} ; 2,5 ; 5, \mathrm{w} 8$; and $7, \mathbf{x}$. The remaining four still had pauciarticular disease and their HLA-DR phenotypes were $2, x ; 1, x ; 3,4$; and 4,5 .

Table 8 Prevalence (\%) of selected $H L A-A, B, C$, and $D R$ antigens in patients with transient arthritis compared with controls

\begin{tabular}{lllll}
\hline$H L A$ & Patients & & & $\begin{array}{l}\text { Controls } \\
(n=78)\end{array}$ \\
\cline { 2 - 4 } & $\begin{array}{l}\text { Men } \\
(n=11)\end{array}$ & $\begin{array}{l}\text { Women } \\
(n=11)\end{array}$ & $\begin{array}{l}\text { All } \\
(n=22)\end{array}$ & \\
\hline A2 & 82 & 36 & 61 & 54 \\
B27 & 17 & 9 & 13 & 10 \\
DR1 & 8 & 18 & 13 & 10 \\
DR2 & $0 \dagger$ & 55 & 26 & 33 \\
DR3 & 17 & 27 & 22 & 19 \\
DR4 & 27 & 27 & 30 & 37 \\
DR5 & 0 & 0 & 0 & 10 \\
DRw6 & 0 & 0 & 0 & 10 \\
DR7 & 0 & 0 & $0+\dagger$ & 28 \\
DRw8 & 0 & 9 & 4 & 9 \\
\hline
\end{tabular}

tp<0.05; $+\dagger p<0.01$; both Fisher's two sided test. 


\section{Discussion}

Even though it is impossible to give a reliable prognosis for an individual patient with JCA, the overall prognosis is favourable. Edström in 1958 noted that $62 \%$ of 85 patients recovered without defects, ${ }^{15}$ and more recently Ansell reported similar figures. ${ }^{1}$ Also in the present study most of the patients with JCA $(32 / 52,62 \%)$ were without peripheral arthritis or sequelae of peripheral arthritis at the clinical follow up examination. Those with TA had an even better outcome; apart from one, all were free of peripheral arthritis at follow up.

In both JCA and TA a surprisingly high prevalence of sacroiliitis was found. In the group with JCA $39 / 46(85 \%)$ had $x$ ray evidence of sacroiliitis, and three also had spondylitis.

The sacroiliac joint is one of the most challenging articulations for the radiologist. ${ }^{14}$ Owing to this or owing to differences in patients or differences in follow up times elapsed before $x$ ray examination, varying prevalences of sacroiliitis in JCA have been found by different workers: Carter found $24 \%,{ }^{16}$ Jeremy and coworkers $43 \%,{ }^{17}$ Veys et al $55 \%,{ }^{18}$ and Arnett et al $28 \% .{ }^{19}$ In a clinical study from northern Sweden, which has a high prevalence of HLA-B27 in the population, ${ }^{20}$ Rantapää Dahlqvist et al observed that in 28 patients with classical adult onset rheumatoid arthritis, selected to be HLA-B27 positive, $82 \%$ had radiographic evidence of sacroiliitis, whereas among 28 HLA-B27 negative controls with rheumatoid arthritis, $57 \%$ had sacroiliitis; the overall prevalence being $70 \%{ }^{21}$

The high prevalence of sacroiliitis in our study may be partly explained by the fact that we chose to take even grade 2 as evidence of radiographic sacroiliitis. This is in accordance with Rantapää Dahlqvist $e t a^{21}$ but in contrast with Arnett et al, ${ }^{19}$ who only included grades 3-4. Jeremy et al studied patients with 'definite' sacroiliitis described as follows: blurring or sclerosis of joint margins, juxtaarticular erosions, or joint fusion. ${ }^{17}$

Of the patients with JCA with grades 3 or 4 sacroiliitis in our study, $8 / 22(36 \%)$ were positive for HLA-B27, which is a low prevalence compared with the findings of Veys and coworkers ${ }^{18}$ and Arnett $e t$ $a l,{ }^{19}$ who found that among patients with JCA with grade 3 and 4 sacroiliitis, $95 \%$ and $93 \%$ respectively were HLA-B27 positive.

In a 10 year follow up study of sacroiliitis in JCA Hall et al found that $9 / 66(14 \%)$ patients had sacroiliitis of the ankylosing spondylitis type. ${ }^{22}$ All were HLA-B27 positive, all presented pauciarthritis, and seven were men. Additionally, they noted sacroiliac changes, interpreted as secondary to hip involvement, in seven patients, of whom six were women and only one, a woman, was B27 positive. In our study only a few patients had their hip joints $\frac{\square}{\omega}$ $x$ rayed at follow up.

Even in the controls, who were older patients in hospital, the prevalence of sacroiliitis was higho $(20 \%)$. There are only a few investigations of the prevalence of sacroiliitis among healthy persons. $\frac{\bar{\rho}}{\bar{\sigma}}$ Cohen et al found erosion of the sacroiliac joint,,$\stackrel{\varnothing}{\varrho}$ subarticular sclerosis, or both, in approximately $6 \%$ of normal subjects under the age of 50 and in $24 \%$ of $^{(2)}$ those over the age of $50 .{ }^{23}$

The finding of multiple associations with HLA antigens confirms and extends earlier reports. ${ }^{3-5}$ Ins the patients with JCA and in those with pauciarticular onset JCA we found a high prevalence of A2, DRw8 and a low prevalence of DR4. In patients with JCA with pauciarticular onset a low prevalence of DR7 $\overrightarrow{-}$ was found, confirming the findings of Hall et al. Men with JCA and grade 3 or 4 sacroiliitis had a slightly higher prevalence of HLA-B27 than women.을 A low prevalence of DR2 was found in patients withJCA and in those with pauciarticular onset of JCA,, 2 in accordance with the findings of Morling et al. ${ }^{4}$

In women with JCA and pauciarticular onset the 3 prevalence of HLA-DRw8 was higher among thosed without peripheral arthritis than in patients who hgd $\overrightarrow{ }$ peripheral arthritis at follow up. If this findinggiso confirmed it could mean that DRw8 is a favourabe prognostic sign in this subgroup of patients. In theo group with TA the prevalence of DRw8 was normals and, with the reservation that only a small numbero of patients with TA was investigated, this findingo could imply that the minimum duration of arthritis $\triangle$ of three months used to defined JCA is relevant. $\overrightarrow{\overrightarrow{0}}$

Most of our patients lived a normal life and didB not have contact with the medical service. Dequeker? and Mardjuadi used a different approach. ${ }^{24}$ They studied patients with JCA still attending an adulto rheumatology or orthopaedic clinic, and the characteristics of their group of patients differed in somes respects from ours. The majority had a later onset than most patients in our study; the mean age ato onset in their group of patients was 10.4 years and that in our 6 years. Whereas only $12 \%(6 / 51)$ of our patients were in functional class III or IV, the corresponding figure in their patients was $25 \%$.

Previous authors have noted that children with polyarticular onset have the worst prognosis. ${ }^{1250}$ Although our group of patients with polyarticula $f$ onset was small, it was interesting that three of the five children were in functional class III. In contrasto the outcome in the children with pauciarticular 06 systemic onset was excellent, with only three of the् 46 being in functional class III or IV.

When the $p$ values were multiplied by the numbero of comparisons the corrected $p$ value $\left(p_{c}\right)$ obtaine $\bar{\Phi}_{\bar{P}}$ 
for the new findings in this study lost statistical significance. Future studies might elucidate further the correlation between HLA and prognosis of JCA.

The skilful assistance of Ms Bodil Noaksson and Ms Inger Johansson is gratefully acknowledged. Supported by grants from the Swedish Society against Rheumatism and the King Gustav V 80 Year Foundation.

\section{References}

1 Ansell B M. Chronic arthritis in childhood. Ann Rheum Dis 1978; 37: 107-20.

2 Bywaters E G L. Juvenile chronic arthritis. In: Ziff M, Velo G, Gorini S, eds. Rheumatoid arthritis. Advances in inflammation research. Vol 3. New York: Raven Press, 1982: 179-90.

3 Anonymous. Juvenile rheumatoid arthritis. In: Tiwari J L, Terasaki P I, eds. HLA and disease associations. New York: Springer, 1985; 64-70.

4 Morling N, Friis J, Heilman C, et al. HLA antigen frequencies in juvenile chronic arthritis. Scand J Rheumatol 1985; 14: $209-16$.

5 Hall P J, Burman S J, Laurent M R, et al. Genetic susceptibility to early onset pauciarticular juvenile chronic arthritis: a study of HLA and complement markers in 158 British patients. Ann Rheum Dis 1986; 45: 464-74.

6 Schaller J G, Ochs H D, Thomas E D, Nisperos B, Feigl P, Wedgewood $\mathbf{R} \mathrm{J}$. Histocompatibility antigens in childhoodonset arthritis. J Pediatr 1976; 88: 926-30.

7 Wood P H N. Special meeting on nomenclature and classification of arthritis. In: Munthe $\mathrm{E}$, ed. The care of rheumatic children. Vol 3, Basel: EULAR, 1978: 47-50.

8 Brewer E J, Bass J C, Baum J, et al. Current proposed revision of JRA criteria. Arthritis Rheum 1977; 20 (suppl 2): 195-9.

9 Svartz N, Schlossman K. The hemagglutination test with sensitized sheep cells in rheumatoid arthritis and some other diseases. Acta Med Scand 1952; 142: 420-32.

10 Pellegrino M A, Ferrone S, Dierich M P, Reisfeld R A. Enhancement of sheep red blood cell human lymphocyte rosette formation by the sulfhydryl compound 2-amino ethyl- isothiouronium bromide. Clin Immunol Immunopathol 1975; 3: 324-33.

11 Ray J G, Hare D B, Pedersen P D, Mullally D I, eds. NIAID manual of tissue typing techniques, 1976: 22. (DHEW publication No (NIH) 76-545.)

12 Bennet P H, Wood P H N. Population studies of the rheumatic diseases. In: Proceedings of the 3rd international symposium, New York, 1966. Amsterdam: Excerpta Medica, 1968: 456-7. (International congress series, No 148.)

13 Steinbrocker O, Traeger C H, Batterman R C. Therapeutic criteria in rheumatoid arthritis. JAMA 1949; 140: 659-62.

14 Bellamy N, Park W, Rooney P J. What do we know about the sacroiliac joint? Semin Arthritis Rheum 1983; 12: 282-313.

15 Edström G. Rheumatoid arthritis in Still's disease in children. A survey of 161 cases. Arthritis Rheum 1958; 1: 497-504.

16 Carter M E. Sacroiliitis in Still's disease. Ann Rheum Dis 1962; 21: 105-20.

17 Jeremy R, Schaller J, Arkless R, Wedgwood R J, Healey L A. Juvenile rheumatoid arthritis persisting into adulthood. Am J Med 1968; 45: 419-34.

18 Veys E M, Coigne E, Mielants H, Verbruggen G. HLA and juvenile chronic polyarthritis. J Rheumatol 1977; 4 (suppl 3): 74-7.

19 Arnett F C, Bias W B, Stevens M B. Juvenile-onset chronic arthritis. Clinical and roentgenographic features of a unique HLA-B27 subset. Am J Med 1980; 69: 369-76.

20 Bjelle A, Cedergren B, Rantapää Dahlqvist S. HLA B27 in the population of northern Sweden. Scand J Rheumatol 1982; 11: 23-6.

21 Rantapää Dahlqvist S, Nordmark L G, Bjelle A. HLA-B27 and involvement of sacroiliac joints in rheumatoid arthritis. J Rheumatol 1984; 11: 27-32.

22 Hall M A, Burgos Vargos R, Ansell B M. Sacroiliitis in juvenile chronic arthritis. A 10 year follow-up. Clin Exp Rheumatol 1987; 5 (suppl 1): 65-7.

23 Cohen A S, McNeill J M, Calkins E, Sharp J T, Schubart A. The 'normal' sacroiliac joint. Analysis of 88 sacroiliac roentgenograms. AJR 1967; 100: 559-63.

24 Dequeker J, Mardjuadi A. Prognostic factors in juvenile chronic arthritis. J Rheumatol 1982; 9: 909-15.

25 Schaller J G, Wedgwood R J. Juvenile rheumatoid arthritis: a review. Pediatrics 1972; 50: 940-53. 